\title{
DAYA SIMPAN SUSU PASTEURISASI DITINJAU DARI KUALITAS MIKROBA TERMODURIK DAN KUALITAS KIMIA
}

\author{
The effect of Pasteurization Milk storage to Quality Microbe Thermoduric and \\ Chemical properties \\ Novita Dewi Kristanti ${ }^{1)}$ \\ 1) Lecture of STTP University Malang, DR. Cipto 144a Bedali Street Malang 65215, ,Indonesia
}

Diterima 27 April 2017, diterima pasca revisi 10 Juli 2017 Layak terbit 1 April 2017

\begin{abstract}
The aim of this study was to determine the quality of thermoduric bacteria and chemical quality of pasteurized milk stored with different time periods. The material was milk from the farmers that was pasteurized at $95^{\circ} \mathrm{C}$ for 21 seconds. The research Method used completely randomized design. The variables observed were TPC, Koliform, Kapang, E. coli bacteria, fat content, protein content, lactose content, total solid, and solid non fat (SNF). The results of the study showed that E. coli and Koliform were not found in pasteurized milk, but a number of thermoduric microbes were found. Pasteurized milk has a shelf life of 30 days under $4^{0} \mathrm{C} \pm$ $10 C$ conditions and has no significant changes in fat content, lactose levels, non-fat dry matter content and protein content.
\end{abstract}

Key words: A shelf life, Thermoduric bacteria,

\section{PENDAHULUAN}

Pengolahan susu segar menjadi susu pasteurisasi merupakan salah satu upaya untuk memperpanjang masa simpan susu tanpa banyak merubah sifat fisiknya. Pasteurisasi susu dilakukan dengan menggunakan proses pemanasan di bawah titik didih susu yaitu $\left(100,16^{\circ} \mathrm{C}\right)$. Kristanti et al (2015) melaporkan bahwa mikroba yang muncul sesaat setelah susu dipasteurisasi diduga sebagai mikroba termodurik. Kontaminasi mikroba dapat terjadi mulai dari pemerahan hingga pengemasan (Kristanti dkk, 2017). Selama proses penyimpanan, susu pasteurisasi diduga akan mengalami perubahan baik sifat kimia maupun karakteristik mikroba. Faktor-faktor yang mempengaruhi kualitas susu

pasteurisasi adalah bahan baku, kondisi pasteurisasi serta kemungkinan kontaminasi. Proses pasteurisasi pada suhu $63^{\circ} \mathrm{C}$ selama 30 menit dan suhu $72^{\circ} \mathrm{C}$ selama 15 detik memberikan dampak terhadap keberadaan spesies, Brucella abortus, Campylobacter jejuni, E. coli, Coxiella burneti, Patogenic E. coli (0157:H7), L. monocytogenes, Mycobacterium tuberculosis, $M$. bovis, Salmonella enterica serotype,
Streptococcus pyogene dan Yersinia enterocolitica (Juffs and Deeth. 2007). Penggunaan suhu $71,7^{\circ} \mathrm{C}$ selama 15 detik, cukup untuk mencapai pengurangan 5-log dari Ookista Cryptosporidium parvum, E. coli O157:H7, Salmonella dan L. monocytogenes (Anonymous, 2010). Santos et al. (2003), menyatakan bahwa susu pasteurisasi pada suhu penyimpanan $9^{0} \mathrm{C}$ atau lebih mempunyai daya simpan hanya sekitar 5 hari dan akan memberikan peluang bagi pertumbuhan $B$. cereus. Sedangkan pada suhu penyimpanan kurang $\quad 7^{\circ} \mathrm{C}, \quad$ bakteri lainnya (psychrotrophic) akan tumbuh cepat dan dapat menyebabkan kerusakan pada susu pasteurisasi. Kerusakan dapat tercapai sebelum koloni $B$. cereus mencapai $1 \times 10^{4} \quad \mathrm{CFU} / \mathrm{mL}$ dan menghasilkan enterotoxin. Valik et al., (2003) menyatakan bahwa pada suhu penyimpanan $4^{\circ} \mathrm{C}$ jumlah koloni $B$. cereus dapat mencapai angka $1 \times 10^{4} \mathrm{cfu} / \mathrm{mL}$ dengan masa simpan susu pasteurisasi sekitar 26 hari, akan tetapi apabila jumlah total mikroba mencapai $5 \times 10^{4} \mathrm{CFU} / \mathrm{mL}$ maka masa simpan susu pasteurisasi hanya mencapai waktu 12 hari. Di Indonesia rata rata masa simpan susu pasteurisasi adalah 5-7 hari. Oleh karena itu perlu diketahui daya simpan susu pasteurisasi pada suhu 
pemanasan yang lebih tinggi yang diharapkan tidak terjadi perubahan secara signifikan pada kandungan gizi susu serta mempunyai masa simpan yang lebih lama.

\section{METODE PELAKSANAAN}

\section{Lokasi Penelitian}

Penelitian dilakukan di Laboratorium Teknologi Hasil Ternak (THT) Fakultas Peternakan, Laboratorium Ternak Perah Fakultas Peternakan dan Laboratorium Mikrobiologi Fakultas Kedokteran Universitas Brawijaya Malang.

\section{Materi Penelitian}

Materi penelitian yang digunakan dalam percobaan ini adalah:

a. Susu segar yang diperoleh dari KUD Dau

b. Susu pasteurisasi dari hasil perlakuan

c. Media untuk analisis mikrobiologi. Media untuk analisis total bakteri adalah PCA (plate count agar). Media yang digunakan untuk analisis koliform adalah lactose broth dan EMBA (Eosin Methylene Blue Agar). Media untuk analisis total $E$. coli adalah VRBA (Violet Red Bile Agar). Media untuk analisis total kapang adalah PDA (Potato Dextrose Agar)

d. Peralatan yang digunakan adalah alat pasteurisasi susu, gelas beker, pipet berskala, sentrifus, butirometer, penangas air, sumbat karet, mikroskop, inkubator, tabung reaksi, autoklaf, termometer, vortex, kaca pengaduk, corong, kertas tisu, kertas label, pipet ukur, pipet tetes, Erlenmeyer, buret dan statif, timbangan analitis, lemari es, cawan petri, colony counter dan lactoscan.

\section{Metode penelitian}

Metode penelitian menggunakan percobaan laboratorium dengan menggunakan Rancangan Acak Lengkap dengan 7 perlakuan dan 3 kali ulangan yaitu:

$\begin{array}{lll}\text { P1 } & =\begin{array}{l}\text { Pasteurisasi } \\ \text { selama 0 hari } \\ \text { Pasteurisasi }\end{array} & \text { disimpan } \\ \text { P2 } & =\begin{array}{l}\text { disimpan } \\ \text { selama 5 hari }\end{array} & \\ \text { Pasteurisasi } & \text { disimpan } \\ \text { selama 10 hari } & \\ \text { P3 } & \text { Pasteurisasi } \\ \text { selama 15 hari } & \text { disimpan } \\ \text { P4 } & \text { Pasteurisasi } \\ \text { Pelama 20 hari } & \text { disimpan } \\ \text { P5 } & =\begin{array}{l}\text { Pasteurisasi } \\ \text { selama 25 hari }\end{array} & \text { disimpan } \\ \text { P6 } & =\begin{array}{l}\text { Pasteurisasi } \\ \text { selama 30 hari }\end{array} & \text { disimpan } \\ \text { P7 } & & \end{array}$

Variabel yang diamati:

Uji TPC, kapang, koliform, bakteri E. coli sesuai petunjuk Sudarwanto (2012). Uji kadar lemak, kadar protein, kadar laktosa, total solid, dan solid non fat (SNF). Analisis data

Data yang diperoleh ditabulasi dan dianalisis dengan analisis varian (ANOVA) dari Rancangan Acak Lengkap, menggunakan program SPSS versi 20. Perbedaan pengaruh dilanjutkan dengan Uji Jarak Berganda Duncan menurut petunjuk Steel and Torrie (1992).

\section{HASIL DAN PEMBAHASAN}

Penentuan kualitas mikrobiologis susu pasteurisasi berupa total bakteri dan total kapang serta kualitas kimia yaitu kadar lemak, kadar laktosa, kadar bahan kering tanpa lemak (SNF) dan kadar protein selama penelitian dapat dilihat pada Tabel berikut.

Tabel Rata-rata Jumlah Bakteri, Jumlah Kapang, Kadar Lemak, Kadar Laktosa, Kadar Bahan Kering Tanpa Lemak, Kadar Protein pada Susu Pasteurisasi Berdasarkan Lama Penyimpan Huruf superskrip pada kolom yang sama menunjukkan perbedaan yang nyata $(\mathrm{p}<0,05)$ 


\begin{tabular}{|c|c|c|c|c|c|c|c|c|}
\hline \multirow[t]{2}{*}{ Perlakuan } & \multicolumn{2}{|l|}{ Mikroba } & \multicolumn{6}{|l|}{ Kimia } \\
\hline & $\begin{array}{l}\text { Log } \\
\text { Bakteri } \\
\text { (CFU/mL) }\end{array}$ & \multirow[t]{2}{*}{$\begin{array}{l}\text { Log } \\
\text { Kapang } \\
(\text { CFU/mL) }\end{array}$} & \multirow[t]{2}{*}{ Lemak } & \multicolumn{2}{|c|}{ Laktosa } & \multicolumn{2}{|l|}{ SNF } & Protein \\
\hline \multicolumn{7}{|c|}{ Susu Pasteurisasi } & & \\
\hline Hari ke -0 & $\begin{array}{l}3,42^{\mathrm{d}} \\
0,38\end{array}$ & - & $\begin{array}{l}3,85^{\mathrm{ab}} \pm \\
0,15\end{array}$ & $\begin{array}{l}4,04^{\mathrm{ab}} \\
0,01\end{array}$ & \pm & $\begin{array}{l}7,35^{\mathrm{a}} \\
0,56\end{array}$ & \pm & $2,86^{\mathrm{Aa}} \pm 0,33$ \\
\hline Hari ke - 5 & $\begin{array}{l}1,93^{\mathrm{c}} \\
0,44\end{array}$ & - & $\begin{array}{l}3,28^{\mathrm{a}} \pm \\
0,69\end{array}$ & $\begin{array}{l}4.05^{\mathrm{ab}} \\
0,10\end{array}$ & \pm & $\begin{array}{l}7,87^{\text {bc }} \\
0,22\end{array}$ & \pm & $2,81^{\mathrm{a}} \pm 0,17$ \\
\hline Hari ke -10 & $\begin{array}{l}1,67^{\mathrm{bc}} \\
0,16\end{array}$ & - & $\begin{array}{l}3,8^{\mathrm{ab}} \pm \\
0,14\end{array}$ & $\begin{array}{l}4,03^{\mathrm{ab}} \\
0,10\end{array}$ & \pm & $\begin{array}{l}7,88^{b c} \\
0,21\end{array}$ & \pm & $2,80^{\mathrm{a}} \pm 0,16$ \\
\hline Hari ke -15 & $\begin{array}{l}1,46^{\mathrm{abc}} \\
0,29\end{array}$ & - & $\begin{array}{l}4,31^{\mathrm{b}} \\
\pm 0,21\end{array}$ & $\begin{array}{l}4,12^{\mathrm{b}} \\
0,11\end{array}$ & \pm & $\begin{array}{l}7,83^{\text {abc }} \\
0,21\end{array}$ & \pm & $2,86^{\mathrm{a}} \pm 0,04$ \\
\hline Hari ke - 20 & $\begin{array}{l}1,41^{\mathrm{ab}} \\
0,23\end{array}$ & - & $\begin{array}{l}4,01^{b} \pm \\
0,41\end{array}$ & $\begin{array}{l}4,04^{\mathrm{ab}} \\
0,04\end{array}$ & \pm & $\begin{array}{l}7,67^{\mathrm{ab}} \\
0,07\end{array}$ & \pm & $2,86^{\mathrm{a}} \pm 0,02$ \\
\hline Hari ke - 25 & $\begin{array}{l}1,28^{a b} \\
0,15\end{array}$ & - & $\begin{array}{l}3,99^{b} \pm \\
0,19\end{array}$ & $\begin{array}{l}3,96^{\mathrm{a}} \\
0,02\end{array}$ & \pm & $\begin{array}{l}8,21^{\mathrm{c}} \\
0,03\end{array}$ & \pm & $2,59^{\mathrm{a}} \pm 0,04$ \\
\hline Hari ke -30 & $\begin{array}{l}1,14^{\mathrm{a}} \\
0,09\end{array}$ & - & $\begin{array}{l}3,99^{\mathrm{b}} \pm \\
0,19\end{array}$ & $\begin{array}{l}3,97^{\mathrm{a}} \\
0,08\end{array}$ & \pm & $\begin{array}{l}8,22^{\mathrm{c}} \\
0,17\end{array}$ & \pm & $2,61^{\mathrm{a}} \pm 0,06$ \\
\hline \multicolumn{9}{|l|}{ Susu Segar } \\
\hline Hari ke -0 & 6,87 & - & 3,89 & 3,97 & & 7,53 & & 2,81 \\
\hline Hari ke -5 & 5,74 & - & 3,73 & 3,84 & & 7,96 & & 2,54 \\
\hline Hari ke -10 & 4,38 & - & 3,73 & 3,91 & & 8,08 & & 2,58 \\
\hline Hari ke -15 & 3,86 & - & 4,39 & 4,24 & & 8,05 & & 3,00 \\
\hline Hari ke -20 & 3,33 & - & 3,9 & - & & - & & - \\
\hline Hari ke -25 & 3,26 & 3,38 & 4 & - & & - & & - \\
\hline Hari ke -30 & 3,57 & 3,49 & 4,2 & - & & - & & - \\
\hline
\end{tabular}

Perlakuan penelitian adalah masa simpan susu pasteurisasi selama 0 hari, 5 hari, 10 hari, 15 hari, 20 hari, 25 hari dan 30 hari, dengan menggunakan suhu pasteurisasi $95^{\circ} \mathrm{C}$ selama 21 detik (Kistanti et al, 2015). Perlakuan menggunakan suhu $95^{\circ} \mathrm{C}$ selama 21 detik, tidak didapatkan $E$. coli maupun koliform. Metode pasteurisasi menggunakan suhu tinggi juga pernah dilakukan oleh Herzallah et al., 2005 yang menggunakan suhu $95^{\circ} \mathrm{C}$ selama 5 menit untuk tube pasteurisasi dan plate pasteurisasi pada suhu $95^{\circ} \mathrm{C}$ selama 15 menit serta Hassan et al., 2009 yang menggunakan suhu $98^{\circ} \mathrm{C}$ selama $0,5-$ 1,87 menit. Variabel yang diamati dalam penelitian ini adalah jumlah total bakteri, total kapang, kadar lemak, kadar laktosa, kadar bahan kering tanpa lemak (SNF) dan kadar protein. Selama penelitian, suhu penyimpanan susu pasteurisasi dijaga antara $4^{0} \mathrm{C} \pm 1^{0} \mathrm{C}$. Harapan yang ingin dicapai adalah susu pasteurisasi dengan kualitas yang sesuai standart dan masa simpan lebih lama. Hasil penelitian diketahui bahwa suhu penyimpanan yang lebih rendah yaitu $4^{0} \mathrm{C} \pm 1^{0} \mathrm{C}$, menghasilkan susu pasteurisasi dengan masa simpan lebih panjang.

Data pada Tabel menunjukkan bahwa pada hari ke 15, kondisi susu pasteurisasi masih stabil, tidak mengalami kerusakan. Menurut Chapman dan Boor (2001), masa simpan susu pasteurisasi dapat mencapai 45 hari, asalkan susu dipasteurisasi pada suhu tinggi atau disebut ultrapasteurisasi. Pada penelitian tahap terakhir digunakan suhu pasteurisasi $95^{\circ} \mathrm{C}$ selama 21 detik. Karena pada pengujian sebelumnya, pada suhu tersebut didapatkan susu pasteurisasi dengan kualitas mikrobiologis yang terbaik. Hasil pengolahan susu pasteurisasi tidak lagi ditemukan koliform dan E. coli.

Menurut Gandy et al. (2008), daya simpan susu pasteurisasi yang disimpan pada suhu $7^{\circ} \mathrm{C} \pm 11^{\circ} \mathrm{C}$ berkisar antara 10 sampai dengan 21 hari. Faktor-faktor yang mempengaruhi kualitas susu pasteurisasi adalah kualitas bahan baku, jumlah bakteri 
awal, kondisi proses pengolahan, bahan pengemas, kontaminasi setelah proses pasteurisasi dan kondisi penyimpanan. Setiap kenaikan suhu penyimpanan $3^{\circ} \mathrm{C}$, maka daya simpan susu pasteurisasi akan berkurang menjadi setengahnya. Jumlah mikroba pada susu pasteurisasi pada hari ke-0 masih tinggi (Log 3,42 CFU/mL), akan tetapi masih sesuai dengan standar SNI yaitu kurang dari $3 \times 10^{4} \mathrm{CFU} / \mathrm{ml}$. Hal ini diduga bahwa jumlah mikroba awal yang tinggi menyebabkan proses pasteurisasi tidak cukup untuk membunuh mikroba secara optimal. Pada hari ke-0 sampai hari ke-5 menunjukkan penurunan total bakteri yang cukup signifikan $(\mathrm{p}<0,05)$. Hal ini diduga bahwa bakteri termodurik yang tahan terhadap suhu pasteurisasi, tidak tahan terhadap suhu dingin, sehingga pada penyimpanan hari ke 5 mengalami penurunan lebih dari 1 siklus log. Penurunan jumlah mikroba sebesar 1 log pada hari pertama sampai hari ke 5 diduga bahwa mikroba yang bertahan pada susu pasteurisasi adalah mikroba termodurik psikrofilik. Yaitu mikroba yang tahan panas tetapi juga mempunyai kemampuan untuk bertahan pada suhu dingin. Penurunan jumlah mikroba juga terjadi pada susu segar yang didinginkan sampai hari ke 30. Tetapi penurunan jumlah mikroba antara hari ke 10 sampai hari ke 30 tidak signifikan. Hal ini diduga bahwa pada susu pasteurisasi bakteri termodurik yang tidak tahan suhu dingin akan mati, sementara bakteri termodurik psikrofilik melakukan adaptasi untuk bertahan pada suhu dingin.

Hasil pengamatan langsung menunjukkan bahwa pada susu pasteurisasi tidak ditemukan E.coli dan koliform, sehingga diduga bahwa mikroba yang mengkontaminasi susu segar dan susu pasteurisasi bukan golongan koliform. Dan hasil pengamatan secara visual diketahui bahwa mikroba yang mengkontaminasi adalah golongan Staphylococcus sp, Streptococcus sp dan Lactobacillus sp. Hal ini sesuai dengan hasil penelitian yang dilakukan oleh Ruegg and Reinemann (2002) yang mengatakan bahwa Streptococcus sp dan Lactobacillus sp. merupakan golongan bakteri termodurik.
Kristanti et al (2015) menemukan bahwa pada susu pasteurisasi menggunakan suhu standar ditemukan mikroba termodurik antara lain Brachybacterium nesterenkovii strain DSM 9573, Kocuria varians strain G33, Klebsiella sp. A4, Chryseobacterium sp. PcRB003, Dermacoccus nishinomiyaensis strain DSM 20448, maupun Pseudomonas otitidis strain $\mathrm{J} 11 \mathrm{~N}$. akan tetapi pasteurisasi pada suhu $95^{\circ} \mathrm{C}$ selama 21 detik tidak ditemukan mikroba termodurik diatas. Tidak adanya mikroba tersebut diduga karena suhu dan waktu pasteurisasi sudah cukup untuk membunuh bakteri termodurik. Mikroba termodurik tidak tahan pada suhu dingin, sehingga mati pada saat penyimpanan dingin.

Menurut Huck et al. (2008) dalam industri pengolahan susu pengendalian bakteri pembusuk pembentuk endospora harus dilakukan, terutama kelompok Bacillus spp dan Paenibacillus. Karena bakteri tersebut dapat bertahan pada suhu tinggi dan waktu pasteurisasi yang pendek. Potensi masuknya mikroba pembusuk tahan panas selama proses produksi dan pengolahan susu dapat berasal dari peternakan sapi perah. Kontrol terhadap bahaya mikrobiologis merupakan tantangan yang cukup besar untuk menjamin kualitas susu pasteurisasi dari sisi keamanan produk. Pendapat di atas diperkuat oleh Ranieri et al. (2009) yang mengatakan bahwa genus Bacillus spp di dalam susu pasteurisasi berperan penting dalam proses pembusukan, sedangkan genus Paenibacillus spp lebih banyak berperan dalam pembusukan saat susu pasteurisasi disimpan dalam kondisi dingin, sehingga berpengaruh terhadap lama penyimpanan. Akan tetapi, dalam produksi susu pasteurisasi sudah tidak ditemukan kelompok Bacillus maupun genus Paenibacillus spp. Kapang mulai muncul pada susu segar setelah penyimpanan hari ke-20. Sedangkan pada susu pasteurisasi tidak muncul kapang. 
Hasil kualitas mikrobiologis susu pasteurisasi hasil penelitian dapat disimpulkan bahwa, kerusakan mikrobiologis pada susu pasteurisasi tergantung dari beberapa faktor. Faktorfaktor tersebut antara lain: adanya mikroba termodurik maupun mikroba kontaminan yang mengkontaminasi susu selama proses pembuatan sampai susu pasteurisasi siap untuk dikonsumsi, suhu dan waktu pasteurisasi, suhu penyimpanan, dan adanya enzim tahan panas yang dihasilkan oleh golongan mikroba tertentu. Keberadaan mikroba pada susu umumnya didukung oleh kandungan nutrisi pada susu sebagai media yang menguntungkan untuk pertumbuhan mikroba.

Lama penyimpanan pada hari ke 0 sampai hari ke 10 tidak berpengaruh nyata terhadap kadar lemak susu pasteurisasi. Lama penyimpanan pada hari ke 15 mulai menunjukkan perbedaan yang nyata. Kadar lemak pada susu pasteurisasi menunjukkan ada peningkatan sedikt pada hari ke 10 dan ke 15, tetapi setelah itu menurun dan cenderung stabil, tetapi kadar lemak lebih tinggi dibandingkan dengan penyimpanan pada hari ke 0 sampai hari ke 10 . Hal ini sesuai dengan pendapat Abubakar dkk. 2001, yang menyatakan bahwa selama penyimpanan, kadar lemak susu pasteurisasi mengalami peningkatan. Menurut Rehman and Salariya, (2005), kerusakan lemak selama penyimpanan diduga karena adanya degradasi lemak menjadi asam lemak, dan apabila kondisi ini berlangsung terus serta suhu penyimpanan dinaikkan, maka akan terjadi lipolisis, atau kerusakan pada lemak. Pada susu segar setelah hari ke-15, kondisi susu segar sudah rusak, sehingga tidak terdeteksi dengan laktocsan. Tetapi hasil uji lemak menggunakan metode gerber menunjukkan bahwa semakin lama penyimpanan kadar lemak menunjukkan peningkatan, walaupun tidak signifikan. Apabila dibandingkan kadar lemak antara susu segar dan susu pasteurisasi menunjukkan bahwa pasteurisasi tidak berpengaruh terhadap kadar lemak. Tetapi reaksi oksidasi tetap dapat terjadi walaupun pada suhu rendah melalui oksigen aktif yang dihasilkan oleh enzim atau melalui paparan cahaya (Claeys et al., 2012 dan 2014). Oksidasi lemak dapat terkendali karena pembentukan antioksidan dalam reaksi maillard, hal ini yang menyebabkan pemanasan dan masa simpan pada suhu dingin berpengaruh sangat kecil terhadap perubahan kadar lemak. Meningkatnya kadar lemak susu pasteurisasi selama penyimpanan dingin, diduga bahwa dalam susu pasteurisasi terdapat mikroba yang dapat mensintesa lemak (Thevenieau and Nicaud, 2012)

Lama penyimpanan pada hari ke 0 sampai hari ke 10 tidak berpengaruh nyata terhadap kadar laktosa dan SNF susu pasteurisasi. Kadar laktosa pada susu pasteurisasi menunjukkan ada peningkatan sedikit pada hari ke 10 dan ke 15, tetapi setelah itu menurun dan cenderung stabil. Menurut (Rehman and Salariya, 2005; Claeys et al., 2014) selama pemanasan penurunan laktosa tidak terlalu signifikan, begitu juga selama penyimpanan. Solid non fat (SNF) merupakan bagian dari total solid kecuali lemak. Lama penyimpanan berpengaruh nyata terhadap SNF susu pasteurisasi setelah hari ke 25 masa penyimpanan. Kecenderungan yang terjadi adalah semakin lama masa penyimpanan, maka kadar SNF semakin meningkat. Menurut Barraquio (2014), kerusakan vitamin $\mathrm{C}$ banyak terjadi selama penyimpanan. Tetapi secara umum SNF selama penyimpanan tidak banyak perubahan secara signifikan. Komponen yang berkurang setelah pasteurisasi adalah Vitamin B1, B6, B9, B12 dan C. tetapi karena jumlahnya tidak terlalu banyak, maka tidak berpengaruh nyata terhadap perubahan komponen gizi susu pasteurisasi. Kerusakan vitamin yang larut dalam lemak (A, D, E dan K) diduga akan mengalami kerusakan tetapi tidak terlalu signifikan, tergantung pada kadar lemak yang mengalami kerusakan.

Lama penyimpanan tidak berpengaruh nyata terhadap kandungan protein susu pasteurisasi. Kerusakan asam amino dalam protein susu protein selama proses pasteurisasi dapat terjadi tetapi dalam jumlah yang sedikit (1-4\%), sehingga tidak berpengaruh terhadap komposisi nutrisi susu pasteurisasi (Anema (2008); Souci et al. (2008); Alvarez et al. (2014)). Kerusakan hanya sedikit terjadi pada protein kasein. Sehingga tidak merubah ikatan peptida. Komponen kasein diduga sebagai senyawa yang dapat meningkatkan ketahanan panas. Proses pemanasan bisa jadi dapat memodifikasi struktur molekul protein, tetapi perubahan tersebut tidak merubah nilai fungsional dari protein seperti kelarutan dan emulisi 
protein, serta tidak berpengaruh secara signifikan terhadap nilai nutrisi. Chavan et al. (2011) menambahkan bahwa pada proses pemanasan dapat terjadi penurunan jumlah mikroba dan inaktivasi enzim. Tetapi proses pemanasan juga menyebabkan dampak yang tidak diinginkan seperti brawning, kehilangan nutrisi, sedimentasi, pemisahan lemak dan rasa gosong. Menurut Barraquio (2014), selama penyimpanan reaksi mailllard tetap berlangsung, tergantung pada kondisi penyimpanan, diantaranya adalah suhu. Kualitas protein di antaranya adalah lysiin, methionin dan sistein akan menurun secara perlahan tetapi tidak signifikan.

\section{DAFTAR PUSTAKA}

Alvarez, V. B. and F. Parada-Rabell. 2014. Health Benefitf $=\mathrm{s}$, Risks, and Regulation of Raw and Pasteurized Milk. Extension FactSheet. Ohio State University Extension's. http://ohioline.osu.edu. Diunduh tanggal 13 juli 2014.

Anema, S. G. 2008. Heat and/or HighPressure Treatment of Skim Milk: Changes to the Casein Micelle Size, Whey Proteins and the Acid Gelation Properties of the Milk. International Journal of Dairy Technology. 61: 245-252.

Anonymous. 1995. Susu Pasteurisasi. SNI 01-3951-1995. Standar Nasional Indonesia. Badan Standardisasi Nasional.2010. FDA Rekommended Pasteurization Time/ Temperatur. Penn State University.

Barraquio, V. L. 2014. Which Milk is Fresh. International Journal of Dairy Science \& Processing. Vol 1 (2): 1 6.

Chapman, K. W., and K. J. Boor. 2001. Acceptance ff $2 \%$ Ultrapasteurized Milk by Consumers, 6 to 11 Years Old. J. Dairy Sci. 84: 951-954.

Chavan, R. S., S. R. Chavan, C. D. Khedkar. and A. H. Jana. 2011. UHT Milk Processing and Effect of Plasmin Activity on Shelf Life: A Review. Comprehensive Reviews in Food Science and Food Safety. 10: 251-268.
Claeys, W.L., S. Cardoen., G. Daube., J. De Block., K. Dewettinck., K. Dierick., L. De Zutter., A. Huyghebaert., H. Imberechts., P. Thiange., Y. Vandenplas. and L. Herman. 2012. Raw or Heated Cow Milk Consumption: Review of Risks and Benefits. Food Control 31: 251- 262.

Claeys, W.L., C. Verraes., S. Cardoen., J. De Block., A. Huyghebaert., K. Raes., K. Dewettinck. and L. Herman. 2014. Consumption of Raw or Heated Milk from Different Species: An Evaluation of the Nutritional and Potential Health Benefits. Food Control 42: 188 - 201.

Gandy, A. L., M. W. Schilling, P. C. Coggins, C. H. White, Y. Yoon. and V. V. Kamadia. 2008. The Effect of Pasteurization Temperature on Consumer Acceptability, Sensory Characteristics, Volatile Compound Composition, and Shelf-Life of Fluid. J. Dairy Sci. 91: 1969-1777.

Hassan, N. B. A., M. O. M. Abdalla. and A. A. A. M. Nour. 2009. Microbiology Quality of Heat-Treated Milk During Storage. Pakistan Journal of Nutrition. 8 (12): 1845 - 1848.

Herzallah, S. M., M. A. Humeid. and K. M. Al-Ismail. Effect of Heating and Processing Methods of Milk and Dairy Products on Conjugated Linoleic Acid and Trans Fatty Acid Isomer Content. J. Dairy Sci. 88:1301-1310

Juffs and Deeth. 2007. Scientific Evaluation of Pasteurisation for Pathogen Reduction in Milk and Milk Products. Food Standars Australia New Zealand.

Kristanti, N. D., Rosyidi, D., Radiati, L. E and Purwadi. 2015. Phylogenetic Tree and Heat Resistance of Thermoduric Bacteria Isolated from Pasteurization Milk in Indonesia. International Journal of Biosciences. 6 (11): 87-98. 
Kristanti, N. D., Warnaen, A dan Daning, D. R. A. Titik Kontrol Kristis pada Pengolahan Susu Pasteurisasi di Koperasi Unit Desa (KUD) Dau Kabupaten Malang. Sains Peternakan 15 (1): 1-7.

Ranieri, M. L., J. R. Huck, M. Sonnen, D. M. Barbano. and K. J. Boor. 2009. High Temperature, Short Time Pasteurization Temperatures Inversely Affect Bacterial Numbers during Refrigerated Storage of Pasteurized Fluid Milk. J. Dairy Sci. 92: 4823-4832.

Reale, S., A. Campanella, A. Merigioli. and F. Pilla. 2008. A Novel Method for Species Identification in Milk and Milk-Based Products. The Journal of Dairy Research. 75: 107-112.

Rehman, Z. U. and A. M. Salariya. 2005. Effect of Storage Condition on Nutritional Quality of UHT Processed Buffalo Milk. Journal Chemical Science. 27 (1): 73 - 76.

Ruegg, P. L. and D. J. Reinemann, 2002. Milk quality and mastitis test. University of Wisconsin Extension Services. The Bovine Prac, 36,1-13.

Santos, M. V., Y. Ma. and D. M. Barbano. 2003.Effect of Somatic Cell Count on Proteolysis and Lipolysis in Pasteurized Fluid Milk during ShelfLife Storage. J. Dairy Sci. 86: 24912503.

Souci, S. W., W. Fachmann. and H. Kraut. 2008. Food Composition and Nutrition Tables. ( $7^{\text {th }}$ ed.).Stuttgart:Wissenschaftliche Verlagsgesellschaft mbH: 1364.

Steel, R. G. D. dan J. H. Torrie. 1989. Prinsip dan Prosedur Statistika; Suatu Pendekatan Biometrik. Gramedia. Jakarta.

Sudarwanto, M. 2012. Pemeriksaan Susu dan Produk Olahannya. IPB Press. Institut Pertanian Bogor. Bogor.

Thevenieau, F and J. Nicaud. 2012. Microorganisms as Sources of Olis. Oilseed \& Fats Crops and Lipid. 6(D603): $2-8$.
Valik L., F. Gorner, and D. Laukova. 2003. Growth Dynamics of Bacillus cereus and Shelf-Life of Pasteurised Milk. Czech Journal Food Science.. 21: 195-202. 